\title{
Some developments on Dutch nutritional approaches to protect piglets against post-weaning gastrointestinal disorders in the absence of in-feed antibiotics
}

\author{
Z. Mroz \\ Institute for Animal Science and Health, ID TNO Animal Nutrition \\ Edelhertweg 15, 8200 AB Lelystad, The Netherlands
}

\section{ABSTRACT}

After withdrawing in-feed antibiotics for prophylaxis against post-weaning syndrome (PWS) and growth promoting in piglets, various research projects have been initiated in the Netherlands towards new aspects of the pathophysiology of PWS and new optional nutritional strategies. In this paper, some current Dutch research topics addressed to the pathophysiology of PWS (microorganisms associated with diarrhoea of weaned piglets, functional histology, enzymatic activity and permeability of the small intestine) and to the post-weaning nutrition in controlling PWS in piglets (probiotics, prebiotics, organic acids, antimicrobial bioactive peptides and immunomodulators, dietary composition) are briefly outlined.

KEY WORDS: pathophysiology, post weaning syndrome, nutrition, piglets

\section{INTRODUCTION}

Yearly losses of piglets in the Netherlands are estimated to be from 100000 to 200000 (Nabuurs, 1991). A substantial part of these losses is ascribed for the postweaning syndrome (PWS), which includes post-weaning diarrhoea, oedema disease and endotoxin shock. Over the past 45 years Dutch farmers have used several in-feed antibiotics or chemotherapeutics for prophylaxis and growth acceleration. However, antibiotic resistance has become a major issue globally along with various regulations banning their use in animal feeds in Europe. At present, only avilamycine, flavomycine and salinomycine are transiently in use. A real perspec- 
tive is that from 2003 exclusively non-antibiotic antimicrobials will be allowed. Meanwhile, Dutch experts looked at how Sweden coped with consequences of banning in-feed antibiotics for piglets over the past 15 years and few research groups initiated extensive programmes on alternative strategies. Whilst acknowledging that non-nutritional strategies (e.g., age at weaning, hygiene of housing, genetical potential, quality of management or stress) are important, this paper focuses on some current Dutch research topics addressed to the pathophysiology of PWS and the role of nutrition in controlling PWS in piglets.

\section{SOME DUTCH DEVELOPMENTS ON THE PATHOPHYSIOLOGY OF PWS IN PIGLETS}

Dutch studies on microorganisms associated with diarrhoea of weaned piglets

As a prerequisite for developing preventive feeding systems in the absence of in-feed antibiotics, the current Dutch research is directed to a better understanding of pathogenesis of PWS. Niewold et al. (2000) indicated that the PWS results from multiple predisposing factors, and a classification of PWS and oedema disease as an Escherichia coli infection is not justified, since also rotavirus may contribute to diarrhoea outbreaks. Besides, swine dysentery (caused by Brachyspira hyodysenteriae), Clostridium perfringens type A and Salmonellosis remain a recurrent problem for the Dutch pig industry. From 5 to $30 \%$ of pig carcasses in the Dutch abattoirs are infected with Salmonella (Roeleveld, 1998). However, Nabuurs (1997) found that the presence of these pathogens in the intestine is not sufficient to cause diarrhoea and they may predominate also the flora of healthy newly weaned piglets. Although porcine enterotoxigenic $E$. coli (ETEC) serotype $\mathrm{K} 88$ predominate as an infective factor associated with the postweaning diarrhoea, different types of enterotoxigenic $E$. coli (ETEC) succeeded each other during the time course, and rotavirus was detected in almost all piglets before and after weaning. The ETEC adhere to the epithelial enterocytes of the small intestine (jejunal section, in particular) of piglets possesing cell receptors via their surface antigens, i.e., pili (fimbrial) adhesins and produce enterotoxins impairing epithelial cell proliferation and nutrient absorption. Healthy and infected villi of pigs are illustrated in Figure 1.

Knowledge on the adherence of enterotoxigenic $E$. coli (ETEC) to the intestinal mucosa is an essential step in the pathogenesis of ETEC induced diarrhoea. Van Zijderveld et al. (1997) studied the anti-adhesive properties of 23 specific monoclonal antibodies $(\mathrm{mAB})$ against the $\mathrm{F} 41$ adhesive fimbrial antigen of ETEC in brush border adhesion inhibition tests and haemaglutination inhibition tests with four F41-positive E.coli strains and purified F41 antigen. The authors con- 


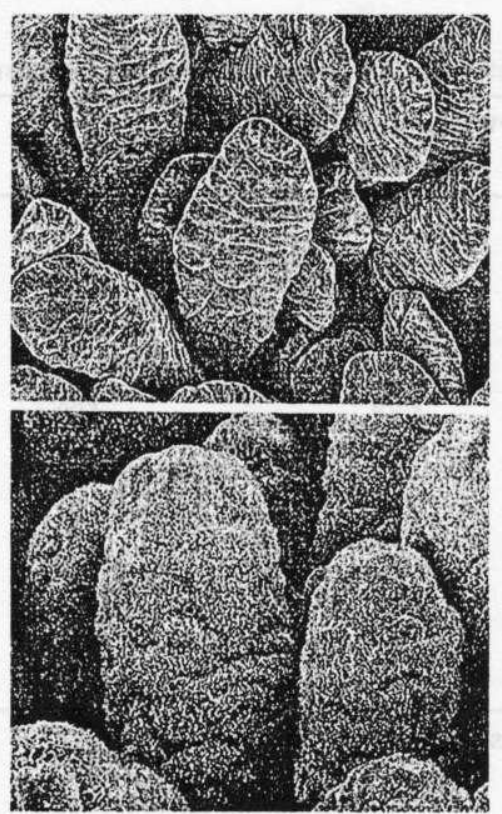

Figure 1. Microscopic view on the surface of healthy and infected intestinal villi of piglets

cluded that direct blocking of the receptor-binding site located on the major fimbrial subunit is not the main mechanism how antibodies protect against ETEC infection, whereas agglutination may be the most important mechanism of protection.

RECENT DUTCH STUDIES ON THE FUNCTIONAL HISTOLOGY, ENZYMATIC ACTIVITY AND PERMEABILITY OF THE SMALL INTESTINE IN WEANED PIGLETS

It is well known that histological parameters and intestinal enzyme activities are closely interrelated with the absorptive capacity and health status of the gastrointestinal tract. In general, major predisposing factors to PWS in piglets are villus shortening and crypt deepening in the small intestine, inflammation of the mucosa, loss of lactogenic protection, susceptibility of enterocytes in the small intestine for pathogen adherence, low level of creep feed intake, dietary allergens, changes in feed ingredients/nutrient contents and malabsorption syndrome.

Results of Nabuurs (1997) on the small intestinal morphology of weaned piglets at 30 days of age from herds without mortality, specific-pathogen free (SPF) and with mortality are presented in Table 1 . These data documented that villi of 
TABLE 1

Measurements of villus height and crypt depth in weaned piglets from 3 herds

\begin{tabular}{lccc}
\hline $\begin{array}{l}\text { Age of pigiets } \\
\text { days }\end{array}$ & $\begin{array}{c}\text { PWS herds without } \\
\text { mortality }\end{array}$ & SPF herd & $\begin{array}{c}\text { PWS herd with } \\
\text { mortality }\end{array}$ \\
\hline $\begin{array}{l}\text { Villus height, } \mu \mathrm{m} \\
30 \text { (weaning) }\end{array}$ & $375^{\mathrm{a}}$ & 425 & $175^{\mathrm{b}}$ \\
34 & 350 & 340 & $160^{\mathrm{b}}$ \\
37 & 350 & 375 & $160^{\mathrm{b}}$ \\
41 & $360^{\mathrm{a}}$ & 450 & $155^{\mathrm{b}}$ \\
44 & $400^{\mathrm{a}}$ & 500 & $155^{\mathrm{b}}$ \\
& & & \\
Crypt depth, $\mu \mathrm{m}$ & & & \\
30 (weaning) & 175 & $25^{\mathrm{c}}$ & 155 \\
34 & 180 & $60^{\mathrm{c}}$ & 160 \\
37 & 215 & $150^{\mathrm{c}}$ & 245 \\
41 & 225 & $150^{\mathrm{c}}$ & 200 \\
44 & 265 & $150^{\mathrm{c}}$ & 225 \\
\hline
\end{tabular}

ab means with different superscript between columns differ at $\mathrm{P}<0.05$

PWS-piglets were shorter and crypts deeper than in SPF-piglets, and therefore, the interrelationship between diarrhoea and epithelial cell proliferation appeared to be evident.

Nabuurs (1997) studied also the effect of weaning by comparing the intestinal morphology between unweaned and weaned littermates over 30 to 44 days of age (Table 2).

The author found that villi shortened and crypts deepened after weaning. However, two weeks after weaning villi of weaned piglets were greater than at weaning and even greater compared to their unweaned littermates. This implies that at a greater villus height are the number of epithelial cells and absorptive capacity of the small intestine also greater.

Van Beers-Schreurs (1996) studied the effect of a weaner diet on the small intestine morphology by comparing unweaned piglets with three groups of piglets weaned at four weeks of age and fed either a commercial weaner diet or sow's milk at high or low levels. The author concluded that the hight of the villi was highest in sucking piglets, although weaned piglets consuming the high level of sow's milk had similar histological parameters. Piglets fed low levels of sow's milk and the commerical weaner diet showed the same villous shortening and crypt deepening. This implies that villus atrophy after weaning is more due to the level of feed intake than to the composition of the diet.

Van Leeuwen and Versantvoort (1999) studied functional parameters of the small intestinal mucosa in piglets fed weaner diets without and with faba bean (Vicia faba L.) tannins (Table 3). 
TABLE 2

Weaning effect on the changes in villus height and crypt depth along the small intestine of piglets

\begin{tabular}{lllllc}
\hline Age of piglets & \multicolumn{5}{c}{ Segment of the small intestine } \\
\cline { 2 - 6 } days & $10^{\%}$ & $25 \%$ & $50 \%$ & $75 \%$ & $95 \%$ \\
\hline Villus height, $\mu \mathrm{m}$ & & & & & \\
30 - unweaned & 475 & 475 & 350 & 355 & 290 \\
30 - weaned & 425 & 485 & 380 & 365 & 310 \\
34 - unweaned & 460 & $440^{\mathrm{a}}$ & 375 & 400 & 310 \\
34 - weaned & 425 & $350^{\mathrm{b}}$ & 340 & 340 & 280 \\
37 - unweaned & $480^{\mathrm{a}}$ & $475^{\mathrm{a}}$ & 410 & 375 & 340 \\
37 - weaned & $420^{\mathrm{b}}$ & $400^{\mathrm{b}}$ & 360 & 350 & 355 \\
41 - unweaned & 525 & 480 & $400^{\mathrm{b}}$ & $360^{\mathrm{b}}$ & 330 \\
41 - weaned & 500 & 505 & $475^{\mathrm{a}}$ & $460^{\mathrm{a}}$ & 390 \\
44 - unweaned & 450 & 475 & $410^{\mathrm{b}}$ & $350^{\mathrm{b}}$ & 340 \\
44 - weaned & 500 & 470 & $475^{\mathrm{a}}$ & $460^{\mathrm{a}}$ & 375 \\
& & & & & \\
Crypt depth, $\mu \mathrm{m}$ & & & & & \\
30 - unweaned & 135 & 128 & 118 & 92 & 95 \\
30 - weaned & 133 & 138 & 120 & 105 & 102 \\
34 - unweaned & 140 & 140 & 138 & 125 & 110 \\
34 - weaned & 158 & 160 & 155 & 160 & 140 \\
37 - unweaned & 160 & 150 & 150 & 138 & 125 \\
37 - weancd & 195 & 190 & 190 & 165 & 160 \\
41 - unweaned & 165 & 160 & 140 & 137 & 120 \\
41 - weaned & 185 & 175 & 178 & 170 & 150 \\
44 - unweaned & 155 & 145 & 140 & 130 & 110 \\
44 - weaned & 183 & 180 & 182 & 170 & 150 \\
\hline
\end{tabular}

ab means with different superscript within columns for particular days after weaning differ at $\mathrm{P}<0.05$

Effects of dietary protein source (milk vs feather) and feeding level (restricted vs ad libitum) on the functional intestinal histology in piglets weaned at 27 days of age were investigated by Verdonk et al. (2000 a). After 14 days post-weaning, the authors examined villous-crypt structure in the small intestine (Table 4). As expected, at the ad libitum feeding, piglets receiving milk protein had higher villous height and crypt depth.

The in vivo transport capacity of fluids, electrolytes and(or) other specific nutrients over the brush border membrane is investigated in the Netherlands with a small intestinal segment perfusion (SISP) model (Figure 2). Also, the nutrient transport across the epithelium and(or) electrophysiological characteristics are tested in vitro with a TNO model, which is a modified flux chamber of Using.

The SISP model was used by Nabuurs (1997) to study the effect of weaning on net absorption in the small intestine of piglets. The mean net absorption of fluid in the ETEC uninfected segments was significantly less in weaned than in 
TABLE 3

Villus height, villus/crypt ratio, mucosal amino peptidase activity and apparent faecal digestibility in piglets fed a control diet or a diet with $20 \%$ of low- or high-tannin faba bean

\begin{tabular}{|c|c|c|c|c|}
\hline \multirow{2}{*}{ Measures } & \multicolumn{3}{|c|}{ Diets } & \multirow{2}{*}{ SEM } \\
\hline & control & low tannin & high tannin & \\
\hline \multicolumn{5}{|l|}{ Villus height, $\mu \mathrm{m}$} \\
\hline proximal jejunum & 590 & 600 & 642 & 55 \\
\hline middle jejunum & 540 & 559 & 599 & 38 \\
\hline distal jejunum & 415 & 448 & 454 & 40 \\
\hline \multicolumn{5}{|l|}{ Villus : crypt ratio } \\
\hline proximal jejunum & 1.9 & 1.8 & 2.0 & 0.2 \\
\hline middle jejunum & 1.8 & 1.9 & 1.9 & 0.1 \\
\hline distal jejunum & 1.7 & 1.9 & 2.1 & 0.2 \\
\hline \multicolumn{5}{|c|}{ Amino peptidase activity, units/g protein } \\
\hline proximal jejunum & $118^{a}$ & $111^{\mathrm{ab}}$ & $66^{\mathrm{b}}$ & 16 \\
\hline middle jejunum & $109^{\mathrm{a}}$ & $108^{\mathrm{a}}$ & $65^{\mathrm{a}}$ & 19 \\
\hline distal jejunum & $109^{a}$ & $140^{\mathrm{a}}$ & $145^{\mathrm{a}}$ & 24 \\
\hline $\begin{array}{l}\text { apparent faecal digestibility of } \\
\text { crude protein, } \%\end{array}$ & $82.9^{a}$ & $82.8^{4}$ & $74.7^{\mathrm{b}}$ & 1.2 \\
\hline
\end{tabular}

TABLE 4

The effect of dietary protcin sourcc (PS) and feeding level (L) on the histological parameters at the proximal (Prox), middle (Mid) and distal (Dist) jejunum of weaned piglets

\begin{tabular}{|c|c|c|c|c|c|c|c|c|}
\hline \multirow{2}{*}{\multicolumn{2}{|c|}{$\begin{array}{l}\text { Intake level } \\
\text { Protein source }\end{array}$}} & \multicolumn{2}{|c|}{ Restricted } & \multicolumn{2}{|c|}{ Ad libitum } & \multicolumn{3}{|c|}{ Significance $^{t}$} \\
\hline & & milk & feather & milk & feather & PS & $\mathrm{L}$ & $\mathrm{PS} \times \mathrm{L}$ \\
\hline \multirow[t]{3}{*}{ Villus, $\mu \mathrm{m}$} & prox & $251^{2}$ & $241^{\mathrm{s}}$ & $330^{\mathrm{b}}$ & $298^{\mathrm{b}}$ & ns & $* * *$ & ns \\
\hline & mid & $249^{a}$ & $242^{\mathrm{a}}$ & $320^{\mathrm{b}}$ & $261^{a}$ & $*$ & $* *$ & $t$ \\
\hline & dist & $169^{a}$ & $184^{a}$ & $266^{\mathrm{c}}$ & $224^{b}$ & ns & $* * *$ & * \\
\hline \multirow[t]{3}{*}{ Crypt, $\mu \mathrm{m}$} & prox & $188^{a}$ & $211^{a}$ & $281^{c}$ & $245^{\mathrm{b}}$ & ns & $* * *$ & $* *$ \\
\hline & mid & $180^{a}$ & $184^{a}$ & $254^{\mathrm{c}}$ & $231^{b}$ & ns & $* * *$ & $t$ \\
\hline & dist & $148^{\mathrm{a}}$ & $160^{\mathrm{a}}$ & $194^{b}$ & $180^{b}$ & ns & $* * *$ & $\mathrm{t}$ \\
\hline \multirow{3}{*}{$\begin{array}{l}\text { Villus } \\
\text { to crypt } \\
\text { ratio }\end{array}$} & prox & 1.4 & 1.2 & 1.2 & 1.2 & ns & ns & ns \\
\hline & mid & $1.4^{\mathrm{a}}$ & $1.3^{\mathrm{ab}}$ & $1.3^{\mathrm{ab}}$ & $1.1^{\mathrm{b}}$ & ns & $*$ & ns \\
\hline & dist & 1.2 & 1.2 & 1.4 & 1.3 & ns & $t$ & ns \\
\hline
\end{tabular}

ns - not significant $(\mathrm{P}>0.1) ;{ }^{*} \mathrm{P}<0.05 ; * * \mathrm{P}<0.01 ; * * * \mathrm{P}<0.001 ; \mathrm{t}=$ tendency $(\mathrm{P}>0.05)$

abc - least square means within a row without a common superscript differ significantly $(\mathrm{P}<0.05)$ 


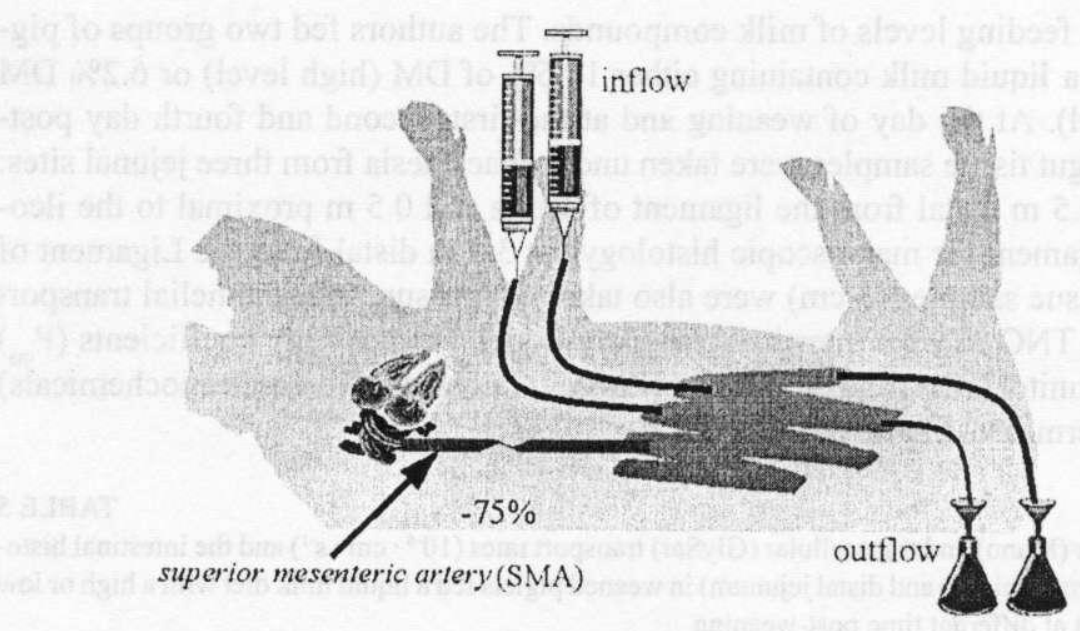

Figure 2. A schematic illustration of the in vivo SISP model to test the net absorption of nutrients at various sites of the small intestine of piglets under anaesthesia for up to $12 \mathrm{~h}$

unweaned piglets on days 4,7 and 14 . The author found remarkable differences between the values for the net absorption of fluid, $\mathrm{Na}$ and $\mathrm{Cl}$ in uninfected and ETEC infected segments at different sites along the small intestine. In uninfected segments net absorption was lowest in the cranial sites, and highest in the caudal sites. In ETEC infected segments, however, net absorption was higher in the cranial and caudal sites than in the middle site of the small intestine. These differences might be due to a specific intestinal colonization pattern of $E$. coli K88+. In another study with the SISP model, Nabuurs (1991) evaluated the effect of of creep feed on net absorption of intestinal fluid in piglets. The results of this study indicate that the decrease in net absorption of fluid usually seen in the uninfected small intestine of piglets after weaning was significantly mildened by providing a creep feed. In piglets receiving a creep feed the net fluid absorption in ETEC-infected segments was improved to a lesser degree compared to uninfected segments. Additionally, it was found that $24 \mathrm{~h}$ after rotavirus infection of the ETEC-infected segments the net absorption was further reduced. This implies that diarrhoea due to ETEC could be aggravated by a concurrent infection with rotavirus.

Studies with the TNO in vitro model showed that permeability across the pig ileal mucosa correlated well with the permeability measured in in vitro models of rat IEC-18 and human colon carcinoma (Caco-2) cell lines (Van Leeuwen and Versantvoort, 1999). Also, this model was used by Verdonk et al. (2000b) to evaluate the permeability of the small intestine in newly weaned piglets as af- 
fected by feeding levels of milk compounds. The authors fed two groups of piglets with a liquid milk containing either $18.6 \%$ of DM (high level) or $6.2 \% \mathrm{DM}$ (low level). At the day of weaning and at the first, second and fourth day postweaning gut tissue samples were taken under anaesthesia from three jejunal sites: 0.5 and $3.5 \mathrm{~m}$ distal from the ligament of Treitz and $0.5 \mathrm{~m}$ proximal to the ileocaecal ligament for macroscopic histology. At $3.5 \mathrm{~m}$ distal from the Ligament of Treitz, tissue samples $(5 \mathrm{~cm})$ were also taken to measure transepithelial transport using the TNO in vitro intestinal transport model. Permeability coefficients $\left(\mathrm{P}_{\mathrm{ms}}\right)$ of ${ }^{3} \mathrm{H}$-mannitol (ICN) and ${ }^{14} \mathrm{C}$-GlySar (Zeneca Cambridge Research Biochemicals) were determined (Table 5).

TABLE 5

Paracellular (Mann) and transcellular (GlySar) transport rates $\left(10^{-6} \cdot \mathrm{cm} \cdot \mathrm{s}^{-1}\right)$ and the intestinal histo. logy (proximal, middle and distal jejunum) in weaned piglets fed a liquid milk diet with a high or low DM content at different time post-weaning

\begin{tabular}{|c|c|c|c|c|c|c|c|c|c|c|c|}
\hline \multirow{2}{*}{$\begin{array}{l}\text { Response } \\
\text { parameters }\end{array}$} & & \multicolumn{3}{|c|}{$\begin{array}{l}\text { DM intake level } \\
\text { with milk, I }\end{array}$} & \multicolumn{4}{|c|}{$\begin{array}{c}\text { Days after weaning } \\
\text { D }\end{array}$} & \multicolumn{3}{|c|}{ Significance? } \\
\hline & & high & low & sem & $0^{\prime}$ & 1 & 2 & 4 & sem & I & $\mathrm{D}$ \\
\hline \multicolumn{12}{|l|}{ Permeability } \\
\hline Mann & mid & $8.2^{\mathrm{a}}$ & $12.1^{\mathrm{b}}$ & 0.9 & 6.6 & $7.8^{x}$ & $11.4^{\mathrm{b}}$ & $11.1^{\mathrm{b}}$ & 0.8 & $* *$ & $* * *$ \\
\hline GlySar & mid & 13.0 & 16.3 & 1.5 & 16.6 & 14.3 & 16.7 & 17.8 & 1.3 & is & Ns \\
\hline \multicolumn{12}{|l|}{ Histology } \\
\hline \multirow[t]{3}{*}{ Villous, $\mu \mathrm{m}$} & prox & $465^{a}$ & $375^{b}$ & 25 & 502 & $443^{a}$ & $355^{\circ}$ & $409^{\text {atb }}$ & 22 & $*$ & $*$ \\
\hline & mid & 370 & 326 & 22 & 351 & $382^{a}$ & $286^{\circ}$ & $319^{b}$ & 19 & ns & $* *$ \\
\hline & dist & 227 & 212 & 13 & 255 & 228 & 207 & 242 & 11 & ns & ns \\
\hline \multirow[t]{3}{*}{ Crypt, $\mu \mathrm{m}$} & prox & 193 & 182 & 7 & 178 & $169^{a}$ & $172^{\mathrm{a}}$ & $196^{\mathrm{b}}$ & 6 & ns & $* *$ \\
\hline & mid & 177 & 171 & 6 & 176 & $163^{a}$ & $161^{a}$ & $189^{b}$ & 5 & ns & $* * *$ \\
\hline & dist & 156 & 152 & 8 & 157 & 143 & 137 & 163 & 7 & ns & $\mathrm{t}$ \\
\hline
\end{tabular}

Groot (1997) studied correlation between electrophysiological phenomena and transport (transcellular/paracellular) of macromolecules in the intestinal epityhelium. The author found from a comparison of electrical phenomena and transport of macromolecules that secretory activity and increased transepithelial transport of macromolecules are related when secretion is mediated by the Ca-ions and protein kinase $\mathrm{C}(\mathrm{PKC})$ dependent pathways. The barrier function of the intestinal epithelium may be diminished during nervous (acetylcholine)- and immuno- (histamine) mediated secretion. The author hypotyhesized that some 
bacterial toxins may also induce Ca-ion and PKC dependent secretion and thereby can reduce the epithelial barrier. The cAMP and cGMP mediated secretion, which can be recognised by their long-lasting transepithelial potential changes, are not coupled to increased transepithelial transport of macromolecules. Thus, some forms of secretory diarrhoea may be related to the development of foodallergy or inflammation.

DUTCH NUTRITIONAL APPROACHES TO PROTECT PIGLETS AGAINST POST-WEANING GASTROINTESTINAL DISORDERS IN THE ABSENCE OF INFEED ANTIBIOTICS

Verstegen and Schaafsma (1999) reviewed some Dutch developments on alternatives for antibiotics as growth promotor. The authors consider probiotics, prebiotics/non digestible oligosaccharides, organic acids, enzymes and modulators of level of microbial activity (herbs) as primary alternatives addressed for Dutch feed industry. So far, few if any have a sound scientific basis combined with consistent performance responses under Dutch practical conditions. Nevertheless, a short outlining of the Dutch research on these alternatives seems useful.

\section{Probiotics}

Until now, the effects of probiotics were more extensive investigated in humans and this has not always led to consistent results. Guarner and Schaafsma (1998) concluded that in humans probiotics reduced signs of lactose intolerance and the duration of several types of diarrhoeal diseases by reducing bacterial enzyme activity, and stimulated the non-specific and specific immune system when challenged by pathogens. The latter was investigated by Maassen et al. (1997) who administered orally wild Lactobacillus strains (L. reuteri, L. casei, L. plantarum and L. murines) in mice. The authors found that Lactobacillus strain dependent cytokine production profiles are induced, which seem to determine the direction and efficacy of the humoral response. Besides, serum antibody responses to i.p. immunisation with chicken gamma globulin in mice appeared to be also modulated by orally administered Lactobacilli. Follow-up studies of Boersma (personal communication) are addressed to develop Lactobacilli as safe live antigen carriers for application in vaccine technology and for the excretion of autoantigens in order to induce tolerance in piglets. Verstegen and Schaafsma (1999) indicated that probiotics may compete for intestinal colonization with pathogenic bacteria and lower LDL cholesterol levels, although more evidence is still required. To substatiate the real value of probiotic products for piglets few projects are currently in progress at the ID-Lelystad. 


\section{Prebiotcs}

Certain carbohydrates (dietetic/fermentable fibres) are resistant to host digestive enzymes, whereas they serve as a substrate for specific friendly colonic microorganisms, which compete for colonisation with pathogens, and thus the host susceptibility to diarrhoea is decreased. Particularly, non-digestible oligosaccharides (NDO) such as mannose oligosaccharides, fructose oligosaccharides and lactulose/glucose oligosaccharides were investigated in a series of Dutch experiments (Alles, 1998; Houdijk, 1998). These authors found that NDO in piglets may ferment completely before entering the large intestine, and therefore microorganisms may use protein as energy source and increase the production of branched chain fatty acids. Also, a combination of NDO with probiotics may be beneficial (Verstegen and Schaafsma, 1999), although still little suportive data is available. In search for an alternative to growth promoters Dutch scientists address their interest to the yeast cell-derived mannanoligosaccharides, phosphorylated mannanoligosaccharides, glucans and peptidoglycans. Few experiments towards elucidating a mode of action of these additives are in progress.

\section{Organic acids}

For several years Dutch feed manufacturers have usually used supplemental organic acids in conjunction with antibiotics for prophylaxis and growth promoting effects (Verstegen and Schaafsma, 1999). Although the organic acid supplementation was initially targeted for weaned piglets, there is a growing evidence that dietary acidification may be beneficial for performance of growing pigs too. Recent results indicate that in growing pigs, organic acids improve the apparent ileal digestibility of protein and amino acids (Mroz et al., 2000), and absorption of minerals (Jongbloed and Jongbloed, 1996), which may contribute not only to improved performance but also to a reduction of nitrogen and phosphorus excretion. In recent years, the pig husbandry has been world wide under increasing pressure to find feasible solutions to improve the efficiency of nitrogen and phosphorus utilization and to reduce their excretion, and dietary acidification may be one possibility to get closer to the target. Organic acids are also known as effective preservatives which by improving the hygienic quality of feeds may further contribute to a better performance of pigs. From a recent in vitro study of Mroz and Van der Meulen (1999) is concluded that adding $50 \mathrm{mmol}$ of acid from 10 different organic acids to buffers of the $\mathrm{pH} 4$ and $\mathrm{pH} 6$ with inoculated with either $10^{7} / \mathrm{mL}$ E. coli serotype $0149 \mathrm{~K} 91$ or Lactobacillus casei. It appeared that of all acids, formic acid, fumaric acid, benzoic acid and capronic acid were most effective in killing E.coli (particularly at the $\mathrm{pH} 4$ ), whereas the number of $L$. casei was only slightly lowered during $6 \mathrm{~h}$ of incubation. 
A recent development is the use of pre-fermented ingredients in a liquid system of feeding after weaning. Despite promising preliminary results, further research is addressed to optimise acidity and composition of liquid byproducts for steering pre-fermentation towards achieving the $\mathrm{pH}$ not below 4.8 (Verstegen and Schaafsma, 1999).

\section{Antimicrobial bioactive peptides and immunomodulators}

Although, in general, it is known that nutrition, immune function and infectious diseases are locked into a complex three-way relationship, termed a complement system, both basic and applied research to understand this relationship in various stages of pig production is of particular importance for Dutch scientists and practitioners.

De Geus et al. (1997) studied prevention of diarrhoea using pathogen specific monoclonal antibodies in an experimental ETEC infection in germ-free piglets. The data of this study showed that $\mathrm{F}_{\text {ac }}$ fimbriae specific monoclonal antibodies $(\mathrm{mAB})$ prevent neonatal diarrhoea in an experimental challenge model in germfree piglets. Currently, the cost of $\mathrm{mAB}$ production is high and therefore, few projects are undertaken to express recombinant $\mathrm{mAB}$ by microorganisms and plants. Meloen et al. (1997) initiated few research projects addressed to „edible vaccines", which can be produced by plant expressed recombinant protein, peptides and viruses. Preliminary experiments are very promising and this development seems very attractive for Dutch practice.

Mroz et al. (1999) evaluated a passive protection of piglets against diarrhoea (due to ETEC K88, K99 and 987P and porcine rotavirus) with specialized egg immunoglobulins $\mathrm{G}(0.0 \mathrm{vs} 1.1 \mathrm{~g} / \mathrm{kg}$ diet $)$ during four different periods of rearing $(22-28,22-42,22-56$ and 28-56 days of age) on the growth rate, feed efficiency, apparent digestibility of nutrients, incidence of diarrhoea and mortality of piglets up to 4 weeks after weaning (Table 6).

Piglets fed IgG over a longer period (days 28-56) had greater daily gains and utilized less feed per kg gain than those given this prodúct over days 22-28 and 2242 , but the differences were not statistically significant. In summary, supplementation of $\operatorname{lgG}$ (titers from 320 to 640 against K88 E.coli) appeared to be effective in improving piglets' resistance against diarrhoea.

There are many bioactive peptides/enzymes (lysozymes, lactoferrins, peroxidases) or herbs addressed to increase the availability of nutrients, and to modify the level of microbial activity (Verstegen and Schaafsma, 1999), although their mode of action is still investigated. 
TABLE 6

Main effects of immunoglobulins $\mathrm{G}(\mathrm{IgG})$ on the feed intake (FI), body weight (BW), average daily gain (ADG), feed conversion ratio (FCR) and losses of piglets (\%) from 28 to 56 days of age

\begin{tabular}{|c|c|c|c|c|c|c|c|}
\hline \multirow{2}{*}{ Main effects } & \multicolumn{2}{|c|}{$\mathrm{IgG}, \mathrm{g} / \mathrm{kg}$} & \multicolumn{5}{|c|}{ Period of rearing with $\operatorname{IgG}$, days of age } \\
\hline & 0.0 & 1.1 & $22-28$ & $22-42$ & $22-56$ & $28-56$ & SED \\
\hline $\mathrm{Fl}$, g/piglet/day & 478.1 & 482.8 & 478.1 & 480.2 & 479.8 & 493.2 & 20.2 \\
\hline $\mathrm{BW}, \mathrm{kg}: 28$ days of age & 7.3 & 7.4 & 7.3 & 7.4 & 7.5 & 7.4 & 0.13 \\
\hline 56 days of age & 16.0 & $16.5^{\circ}$ & 16.3 & 16.3 & 16.6 & 16.6 & 0.14 \\
\hline ADG, g/day & 311.1 & $323.2^{* *}$ & $319.6^{\mathrm{a}}$ & $317.1^{\mathrm{a}}$ & $326.1^{\mathrm{ab}}$ & $330.0^{b}$ & 5.43 \\
\hline $\mathrm{FCR}$ & 1.54 & $1.49^{\circ}$ & 1.50 & 1.51 & 1.47 & 1.49 & 0.02 \\
\hline \multicolumn{8}{|l|}{ Losses of piglets } \\
\hline total & 7.6 & $2.5^{\circ}$ & 2.3 & 2.4 & 2.3 & 2.5 & 0.2 \\
\hline due to $E$. coli, \% & 4.8 & $0.0^{\circ}$ & 0.0 & 0.0 & 0.0 & 0.0 & 0.0 \\
\hline
\end{tabular}

${ }^{\mathrm{P}}<0.05 ;{ }^{\circ} \mathrm{P}<0.01$; ${ }^{\text {ab }}$ means with different superscripts in the period of rearing differ at $\mathrm{P}<0.05$

\section{Dietary composition}

In the era before antibiotics were developed, piglets with enteric bacterial infections were fed, for example, with oats soaked in salt water. The detailed compositions of commercial piglet starter diets are largely secret and have been based on unpublished in-house research. In view of the importance of achieving high intakes of feed early in the post-weaning period, attention is paid to its chemical and physical characteristics. Skim milk powder and other dried-milk products have been the most valuable feedstuffs for starter diets. Vegetable proteins present a range of problems to the immature digestive system (,,anti-nutritional factors" and ,,antigenic" reactions). Much of our knowledge of the roles of individual nutrients in inflammatory responses or immune function is derived from nutrient deficiency studies. An understanding of the immunologic roles of individual nutrients may prove useful for designing nutritional strategies, particularly for critical transitional periods after post-weaning. Deficiencies in certain of the essential nutrients can impair the immune system, and other host defensive mechanisms in more than one way. Since most antigens (allergens) are proteinaceous compounds, it is not surprising that immune response to certain protein containing feed ingredients (e.g., lectins, phytohaemaglutinin [PHA]) have been found. These substances are resistant to proteolysis during passage through the alimentary tract, and may bind carbohydrates on epithelial cells, and after binding, they are endocytosed and can subsequently cause an immune response. It is also well established that there are important interactions between dietary protein, some specific amino acids and immune function. Protein depleted pigs showed an impaired immune competence, largely due to an insufficient synthe- 
sis of the cellular proteins of the immune system and an inadequate supply of amino acids to support the hepatic acute phase protein response. Few Dutch studies addressing protein deficiency and immunocompetence in pigs have focused on antibody-mediated immunity, although the measurements of antibody titers only do not indicate the relative affinity of those antibodies for antigen. Furthermore, antigens in adjuvants were also administered that act to increase antigen processing by eliciting inflammatory cells and to release antigen continuously over longer time periods. Therefore, if dietary treatments affect antigen processing or clearance, these effects would be masked by the use of an adjuvant. Nonetheless, as for most nutrient deficiencies, available data indicate that antibody-mediated immune responses are substantially reduced by moderate protein deficiencies. The metabolic end products of some amino acids are also crucial intermediates in the maintenance of a variety of defense functions that bear no direct relationship to protein metabolism. Glutathione (a tripeptide and a key free radical scavanger) is synthetized from glutamate/glutamine, glycine and cysteine, and its restoration by depleted animals is achieved by the simple provision of cysteine in the diet. Recent Dutch work indicates a specific role of arginine in the regulation of inflammation (and perhaps immune function) since nitric oxide production from arginine plays an important role in macrophage cytotoxic functions and in the interactions between macrophages and lymphocyte adhesion and activation. As a part of the structure of mucus glycoproteins, threonine contributes to one of the most extensive and important innate defense barriers against bacterial and viral invasion. Approximately $90 \%$ of the mass of the mucus glycoproteins covering epithelial surfaces of the intestine and lung are carbohydrates. These complex carbohydrate side chains are attached to an extensively sulphur cross-linked core protein particle via $\mathrm{O}$-glycosylic linkages largely formed from the hydroxyl group of threonine, an amino acid that contributes $22 \%$ by weight of the core protein. As these proteins are continually secreted from the external surfaces of the intestine and lung, their continual synthesis persistently drains an individual's threonine supplies. Despite glutamine is an abundant free amino acid in the plasma of pigs, but its extra supplementation (1\%) seems to serve as a mojor fuel for rapidly dividing lymphocytes, for maintenance of gut associated lymphatic tissues and production of secretory immunoglobulin A, intestinal integrity and the prevention of bacterial translocation from the gut (Schraama, personal communication). There is also a reasonable indication that immunologic stress (e.g., injection of bacterial lipopolysaccharides) alters protein metabolism. Leukocytic cytokines decrease the rate of skeletal muscle protein accretion while preserving and enhancing the production of specific liver proteins.

Some of the above aspects are currently studied in the frame of the EU project entitled: "Defining and validating gut health criteria in young pigs, based on digestive physiology, microbiology and mucosal immunology investigations for 
testing alternative strategies to in-feed antibiotics". This project is designed for three years (2001-2003), with complementary contributions of the ID-Lelystad, University of Wageningen and the Cooperative Institute of Nutrition „Schothorst” in Lelystad.

\section{REFERENCES}

Alles M.S., 1998. Physiological effects of consumption of fructo-oligosaccharides and transgalactooligosaccharides. PhD Thesis, Wageningen University (The Netherlands)

De Geus B., Harmsen M., Van Zijderveld F., 1997. Prevention of diarrhoea using pathogen specific monoclonal antibodies in an experimental enterotoxigenic E.coli infection in germfree piglets. Vet. Quart. 20 (3), S87.S89

Groot J.A., 1997. Correlation between electrophysiological phenomena and transport of macromolecules in intestinal epityhelium. Vet. Quart. 20 (3), S45-S49

Guarner F., Schaafsma G.J., 1998. Probiotics. Int. J. Food Microbiol. 39, 237-238

Houdijk J.G.M., 1998. Effects of non-digestible oligosaccharides in young pig diets. PhD Thesis. Wageningen University (The Netherlands)

Jongbloed A.W., Jongbloed R., 1996. The effect of organic acids in diets for growing pigs on enhancement of microbial phytase efficacy. ID-DLO Report No. 96009, Institute for Animal Science and Health, Lelystad (The Netherlands)

Maassen C.B.M., van Holten J.C.A.M., Balk F., Heijne den Bak-Glashouwer M.J., Leer R., Laman J.D., Boersma W.J.A., Claassen E., 1997. Orally administered Lactobacillus strains differentially affect the direction and efficacy of the immune response. Vet. Quart. 20 (3), S81-S83

Meloen R.H., Hamilton W.D.O., Casal J.I., Dalsgaard K., Langeveld J.P.M., 1997. Edible vaccines. Vet. Quart. 20 (3), S92-S95

Mroz Z., Grela E.R., Matras J., Krasucki W., Kichura T., Shipp T.E., 1999. Passive protection of piglets against diarrhoea with specialized egg immunoglobulins (PROTOMAX ${ }^{\circledR}$ ). In: P.D. Cranwell (Editor). Manipulating Pig Production VII, 238. Australian Pig Science Association, Werribec, Victoria (Australia), pp. 238

Mroz Z., Jongbloed A.W., Partanen K.H., Vreman K., Kemme P.A., Kogut J., 2000. The effects of calcium benzoate in diets with or without organic acids on dietary buffering capacity, apparent digestibility, retention of nutrients, and manure characteristics in swine. J. Anim. Sci. 78, 26222632

Mroz Z., Van der Meulen J., 1999. Health and functional features of the small intestine in pigs fed organic acids. In: Proceedings Symposium of the Dutch Central Bureau for Livestock Feeding on „Feeding and Health of the Digestive Tracı". Onderzoeksreeks, Wageningen (The Netherlands), 4, 13-19

Nabuurs M.J.A., 1991. Etiologic and pathogenic studies on postweaning diarrhoea. PhD Thesis. State University of Utrecht (The Netherlands)

Nabuurs M.J.A., 1997. Weaning piglets as a model for studying pathophysiology of diarrhoea. Vet. Quart. 20 (3), S42-S45

Nabuurs M.J.A., Hoogendoom A., van Zijderveld F.G., van der Klis J.D., 1993. A long-term perfusion test to measure net absorption in the small intestine of weaned pigs. Res. Vet. Sci. 56, 379-385

Roeleveld M., 1998. The European Union intends to prevent and control rigorously infections with Salmonellà. Varkens (Pigs), 5 May, pp. 48-49 
Van Beers-Schreurs II.M.K, 1996. The changes in the function of the large intestinc of wcaned pigs. PhD Thesis. State University of Utrecht (The N'ctherlands)

Van Lecuwen P., Versantvoor C.H.M., 1999. Functional histology of the small intestinal mucosa in livestock production animals. In: Nutrition and Gastrointestinal Physiology - Today and Tomorrow. Wageningen (The Netherlands), pp. 9-21

Van Zjjderveld F.G., van Zijderveld-van Bemmel A.M., Bakker D., 1997. The F41 adhesion of cnterotoxigenic Escherichia coli: inhibition of adhesion by monoclonal antitodies. Vet. Quart. 20) (3), S73-\$78

Verdonk J.M.A.J., Sprecuwenberg M.A.M., Bakker G.C.M., Verstegen M.W.A., 2000 a. Effect of protein source and feed intake level on histology of the small intestine in newly weaned piglets. In: Proceedings of Symposium: Digestion Physiology in Pigs. Uppsala (Sweden)

Verdonk J.M.A.J., Sprecuwenberg M.A.M., Bakker G.C.M., Verstegen M.W.A., 2000 b. Nutrient intake level affects histology and permeability of the small intestine in newly weaned piglets. In: Proceedings of Symposium Digestion Physiology in Pigs. Uppsala (Sweden)

Verstegen M.W.A., Schaafsma G.J., 1999. Some developments on alternatives for antibiotics as growth promotor. In: Nutrition and Gastrointestinal Physiology - Today and Tomorrow. Wageningen (The Netherlands), pp. 65-73

\section{STRESZCZENIE}

Rola żywienia jako czynnika zapobicgającego zaburzeniom przewodu pokarmowego odsadzonych prosiąt nieatrzymujących antybiulyków w paszy - w świetle badaj́ holenderskich

Po wycofaniu antybiotyków paszowych, stosowanych profilaktycznie przeciw zespotowi poodsadzeniowemu (PWS) i jako promotory wzroslu prosiąt, w Holandi zainicjowano różne projekly badawcze nad nowymi aspektami patofizjologii PWS i nowymi alternatywnymi systemami zywienia. W pracy omówiono niektóre zagadnienia stanowiące przedmiot badan prowadzonych w Holandii nad patofizjologią PWS (drobnoustrojc związane z biegunką odsadzonych prosiąt, histologia, aklywność enzymatyczna i przepuszczalność jelita cienkiego) oraz nad żywicnicm w oktesic po odsadzeniowym, jako czynnikiem zapobiegającym PWS (probiotyki, prebiotyki, kwasy organiczne, antybakteryjne bioaktywne peptydy i modulatory systemu odpornościowego, skład diet). 